\title{
Skenario Dinamis Menggunakan Finite State Machine pada Game Pengenalan Tempat dan Peristiwa Bersejarah
}

\author{
Surya Adijaya Saputra ${ }^{1}$, Hanny Haryanto ${ }^{2}$, Erlin Dolphina ${ }^{3}$ \\ Program Studi Teknik Informatika, Universitas Dian Nuswantoro \\ Jalan Imam Bonjol 207 Semarang, (+6224) 3517261 \\ e-mail: ${ }^{1}$ suryaadijaya28@ gmail.com, ${ }^{2}$ hanny.haryanto@dsn.dinus.ac.id, ${ }^{3}$ erlin.dolphina@dsn.dinus.ac.id
}

\begin{abstract}
Abstrak
Sejarah adalah studi masa lampau khususnya bagaimana kaitannya dengan manusia. Dalam bahasa Indonesia hikayat riwayat ataupun tambo dapat diartikan sebagai peristiwa yang benar-benar sudah terjadi pada masa lampau atau asal-usul. Belajar sejarah secara konvensional di bangku sekolah cenderung membosankan dan menjadi kendala bagi sebagian besar pelajar di Indonesia. Oleh karena itu, diperlukan inovasi pembelajaran yang menarik. Game saat ini banyak digemari oleh semua kalangan baik anak-anak hingga dewasa, sehingga hal ini membuat game edukasi menjadi sarana pembelajaran alternatif yang menarik untuk mengenalkan sejarah secara menyenangkan. Di Indonesia, banyak tempat dan peristiwa bersejarah yang kurang dikenal contohnya benteng Pendem Cilacap, Benteng Pendem Ambarawa, Benteng Rotterdam, Benteng Portugis Jepara dan Benteng Marlborough. Salah satu genre game yang menceritakan skenario adalah visual novel, akan tetapi pilihan skenario yang monoton membuat game membosankan. Diperlukan implementasi kecerdasan buatan untuk membuat pengalaman pada scenario yang dinamis. Penelitian ini menggunakan metode Finite State Machine yang diimplementasikan pada pilihan skenario dalam game visual novel. Finite State Machine mengatur perilaku dari scenario yang ada. Hasil dari penelitian ini adalah pilihan skenario cerita yang beragam dan dinamis sehingga dapat meningkatkan pengalaman bermain dan membuat game edukasi menjadi menarik dan menyenangkan.
\end{abstract}

Kata kunci: Game, Edukasi, Sejarah, Visual Novel, Finite State Machine.

\begin{abstract}
History is a study of the past, especially how it relates to humans. In Indonesia, the history or tambo saga can be interpreted as an event that really happened in the past or origin. Conventional learning history in school tends to be boring and is an obstacle for most students in Indonesia. Therefore, interesting learning innovations are needed. Games today are much loved by all groups of children to adults, so this makes educational games an attractive alternative learning tool to introduce history in a fun way. In Indonesia, many historical places and events are less well known such as the Cilacap Pendem Fortress, Ambarawa Pendem Fortress, Fort Rotterdam, the Portuguese Fort Jepara and Fort Marlborough. One genre of games that tells a scenario is a visual novel, but the choice of a monotonous scenario makes the game boring. The implementation of artificial intelligence is needed to make the experience in a dynamic scenario. This study uses Finite State Machine method which is implemented in the choice of scenarios in visual novel games. Finite State Machine directed the behavior of the scenario. The results of this study are a selection of diverse and dynamic story scenarios that can enhance the playing experience and make educational games interesting and fun.
\end{abstract}

Keywords: Game, Education, History, Visual Novel, Finite State Machine.

\section{Pendahuluan}

Sejarah adalah studi tentang masa lampau khususnya bagaimana kaitannya dengan manusia, dalam Bahasa Indonesia hikayat riwayat atau tambo dapat diartikan sebagai kejadian atau peristiwa yang benar terjadi pada masa lampau atau asal usul [1]. Memahami sejarah khususnya pada manusia merupakan hal yang penting dalam melestarikan budaya bangsa, di samping itu ada fungsi sosiokultural yang dapat membangkitkan kesadaran nasionalis [2]. Belajar sejarah menjadi kendala sebagian pelajar di Indonesia karena cenderung membosankan. Di Indonesia banyak tempat-tempat bersejarah dan peristiwanya yang 
kurang dikenal oleh masyarakat contohnya Benteng Pendem Cilacap[3], Benteng Pendem Ambarawa, Benteng Portugis Jepara, Benteng Rotterdam, Benteng Marlborough dan masih banyak yang lainnya,

Game saat ini terus berkembang baik anak-anak hingga dewasa suka bermain game. Di dalam Sebuah game terdapat unsur - unsur yang penting untuk membentuk pengalaman bermain. Berdasarkan buku Artificial Intelligence [4] terdapat unsur Adaptivity Challenges, yaitu ada beberapa bagian penting dalam game, yaitu NPC, mechanic, AI, game world, skenario atau quest. salah satu unsur yang penting dalam game yaitu skenario atau quest adalah jalan cerita garis besar kejadian yang ada pada game salah satu game yang inti permainannya menceritakan skenario adalah Visual Novel [5] akan tetapi pilihan skenario yang statis menyebabkan pemain cepat bosan karena mengarah pada scene yang terkesan mudah ditebak untuk itu dibutuhkannya implementasi kecerdasan buatan agar pilihan skenario menjadi dinamis. Salah satu metode yang dapat membuat skenario dinamis yaitu finite State Machine [6] karena state aktif dapat bertransisi atau beralih ke state lain dengan keadaan tertentu sehingga state akan berubah sesuai kondisi dari dalam maupun luar perangkat.

Penelitian yang menjadi acuan adalah oleh Tito Bimantoro, Hanny Haryanto [7] menggunakan metode Finite State Machine digunakan untuk memberikan variasi respons yang dinamis pada agen cerdas atau NPC dapat dilihat pada Gambar 1 di bawah ini

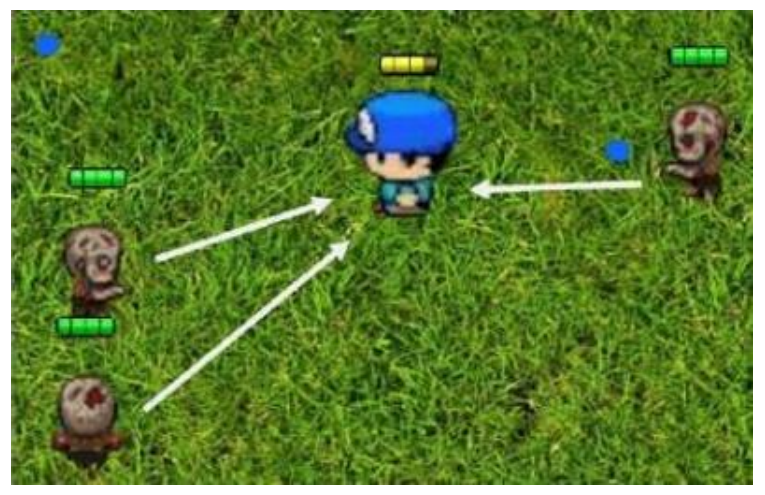

Gambar 1. Musuh kategori B[7].

Pada gambar di atas menunjukkan kondisi musuh kategori B sedang mengejar atau menembak. Butiran biru pada gambar merupakan peluru yang ditembakkan musuh terhadap pemain peluru yang mengenai target tepat sasaran akan mendapatkan damage. Pengurangan damage Sesuai dengan jenis senjata yang ditembakkan.

Penelitian yang menjadi acuan kedua adalah penelitian yang dilakukan oleh Hanny Haryanto[8] menggunakan metode Finite State Machine dalam menentukan hadiah atau reward dinamis metode tersebut terlihat pada Gambar 2.

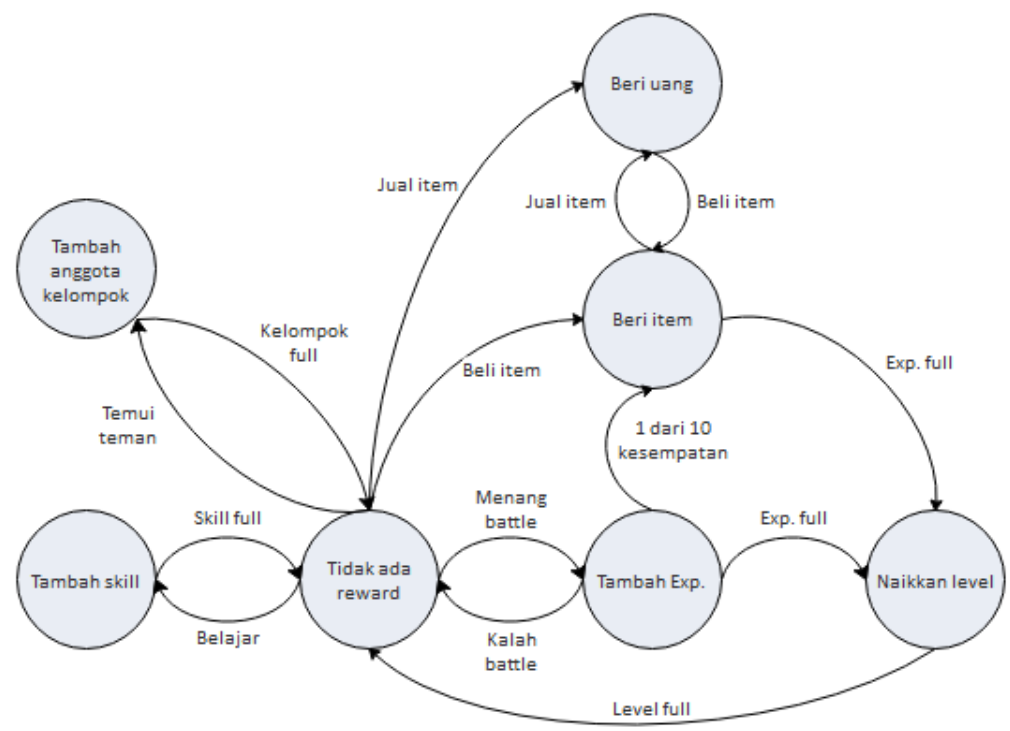

Gambar 2. Diagram reward dinamis [8]. 
Dalam penelitian tersebut terdapat reward dinamis setiap pilihan yang dilakukan oleh pemain di dalam game menentukan reward yang didapatkannya. Rancangan FSM tersebut menunjukkan bahwa state tidak ada reward akan beralih pada state beri uang apabila pemain memilih kondisi jual item. State beri uang dan beri item dapat beralih ke masing-masing state dengan kondisi-kondisi tersebut ketika menang battle state akan beralih ke state tambah exp. Jika kalah battle maka akan mengaktifkan state tidak ada reward.

Penelitian yang menjadi acuan ketiga yaitu penelitian yang dilakukan oleh Miftah Fauzan Rahardian, Addy Suyatno, Septa Maharani [9] menggunakan metode Finite State Machine pada penelitiannya untuk menentukan berbagai macam respons dinamis NPC yang terlihat pada Gambar 3 di bawah ini.

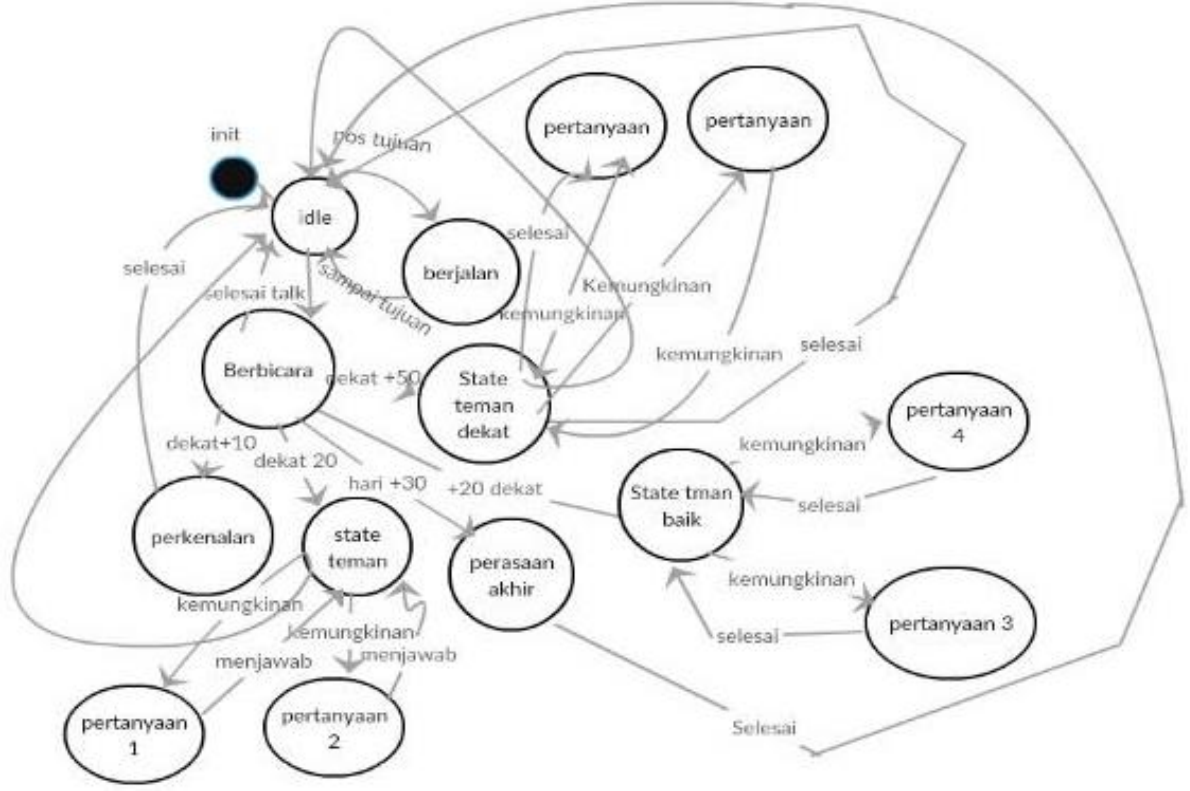

Gambar 3. Respons NPC terhadap pemain [9].

State diagram dari penelitian tersebut menjelaskan Finite State Machine yang diterapkan pada NPC utama yaitu karakter Mira, Fina, dan Tara untuk memberikan respons yang berbeda jika mendapatkan masukan dari pemain. Pada saat game dimulai NPC akan langsung bertransisi menuju state idle. NPC akan bertransisi menuju state berjalan ketika NPC diatur untuk berjalan menuju arah tujuan tertentu hingga NPC berada pada posisi tujuan. Sedangkan ketika NPC menyentuh player akan bertransisi menuju state berbicara yang akan menyesuaikan tingkat kedekatan player dengan NPC berdasarkan variable NPC. Dari penelitianpenelitian tersebut didapatkan bahwa Finite State Machine dapat mengatur perilaku dinamis, yang pada penelitian ini digunakan untuk mengatur perilaku dinamis pada skenario.

\section{Metode Penelitian}

\subsection{Pengumpulan Data dan Proses Menentukan Skenario}

Pengumpulan data tentang bangunan bersejarah dilakukan melalui studi literatur. Setelah data bangunan bersejarah didapatkan, kemudian disusun skenario utama yang merupakan inti dari permainan. Proses prosedurnya dapat di lihat pada Gambar 4. 


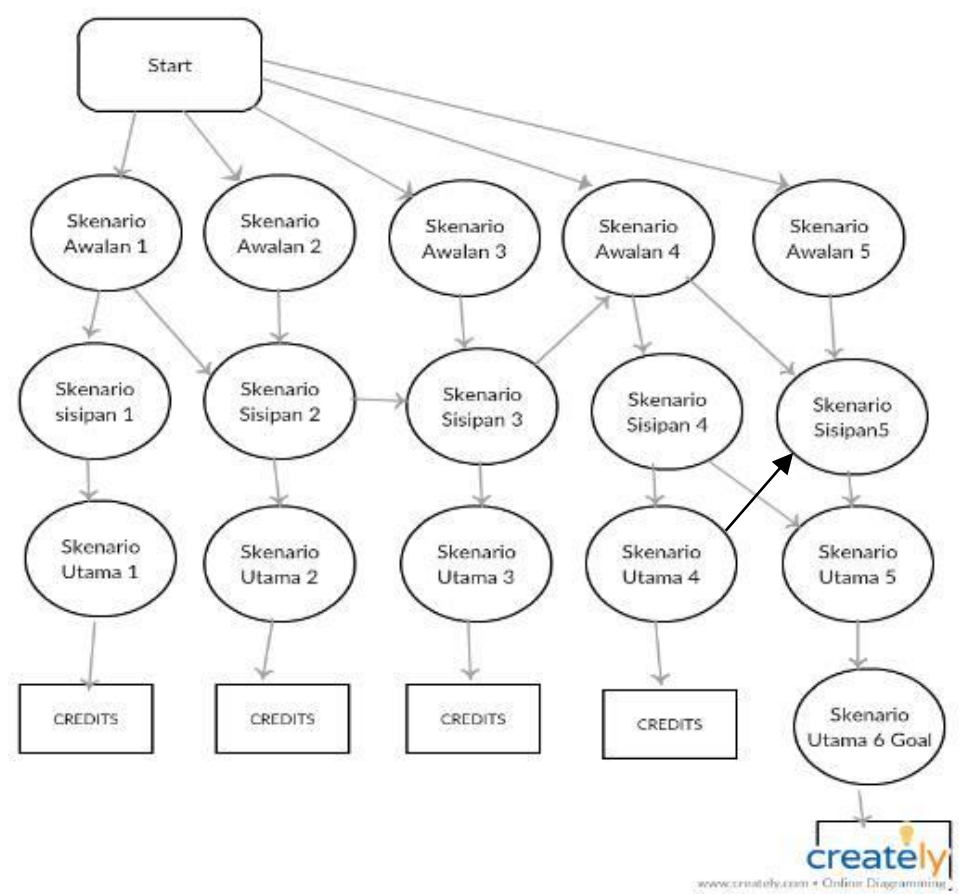

Gambar 4. Alur penentuan skenario pada diagram FSM.

Berdasarkan gambar di atas pemain dapat memilih total 5 skenario awalan untuk memulai game yang masing-masing saling berbeda dan akan diteruskan bertransisi ke state skenario sisipan yang tersedia dan akan melanjutkan ke skenario utama dan selesai pada state credits pada skenario tertentu pemain akan mendapatkan pertanyaan dan diharuskan untuk menjawab dan akan menerima state reward.

\subsection{Penentuan Arah Skenario dengan Finite State Machine}

Berdasarkan Gambar 1 pemain yang telah memilih dari beberapa pilihan scenario awal saat mulai bermain akan mulai masuk ke dalam jalur-jalur skenario cerita yang sudah ditentukan. Member pemain memilih awal bermain dengan skenario awal no. 3 pemain dapat memutuskan untuk memilih meneruskan ke scenario sisipan no. 3 atau berpindah ke awal skenario ke 4 anggap saja kita memilih meneruskan cerita ke skenario no. 4 kita masih dapat 2 pilihan berbeda untuk melanjutkan permainan baik meneruskan ke skenario sisipan no. 4 atau skenario sisipan no. 5 yang masing-masing membuka kemungkinan untuk memainkan skenario utama yang berbeda pula sehingga pemain tidak merasa cepat bosan. 


\subsection{Gambaran Finite State Machine Secara Umum pada Game}

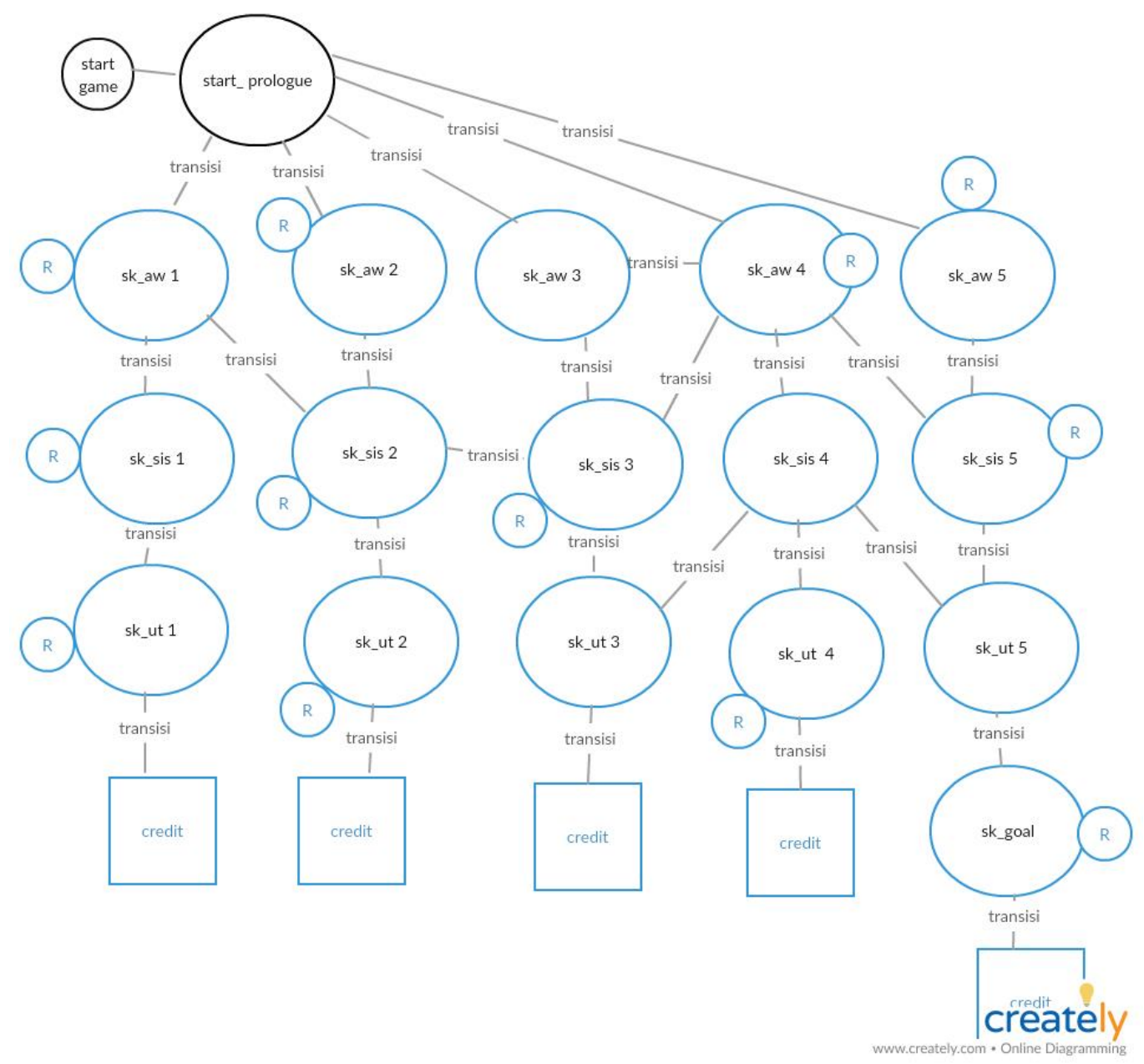

Gambar 5. Gambaran umum FSM pada game.

Pada gambar 5 di atas merupakan gambaran umum game yang diimplementasikan dengan finite state machine setelah memulai game maka akan memasuki state_prologue setelah dijalankan pemain dihadapkan dengan event yang akan dipilih oleh pemain dan akan bertransisi ke salah satu dari 5 (sk_aw) skenario awal yang berisi pertanyaan dengan kondisi $(\mathrm{R})$ reward yang berbeda satu dengan lainya akan tetapi (state) atau keadaan tidak bertransisi ke state lain setelah menjawab pertanyaan dan menerima reward poin, pemain dihadapkan dengan event transisi ( $\left.s k \_s i s\right)$ atau skenario sisipan jika ada event kondisi menjawab pertanyaan dan mendapat reward yang berbeda-beda state tetap berada pada skenario sisipan setelah menyelesaikan cerita pada state $s k \_s i s$ maka event akan bertransisi pada skenario utama (sk_ut) jika ada pertanyaan pemain dapat menjawab tetapi keadaan state tidak berubah dan dilanjutkan dengan transisi ke state credit dan game pun selesai. 
3. Hasil dan Pembahasan

3.1. Diagram Skenario Dinamis yang ada pada Game

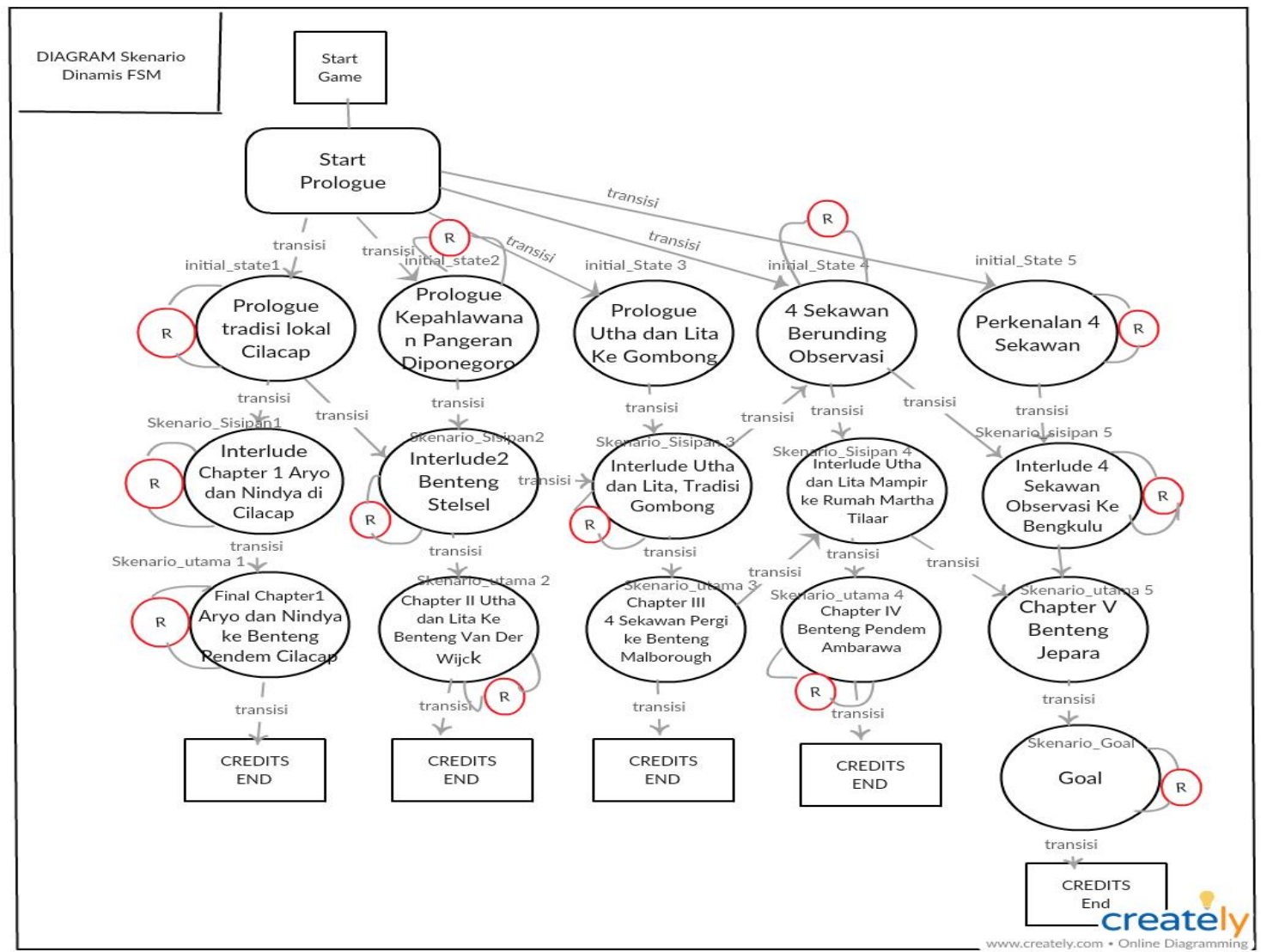

Gambar 6. Skenario dinamis menggunakan FSM.

Gambar 6 merupakan skenario dinamis yang dihasilkan dengan menggunakan Finite State Machine.

\subsection{Contoh Diagram Reward Dinamis pada Game}

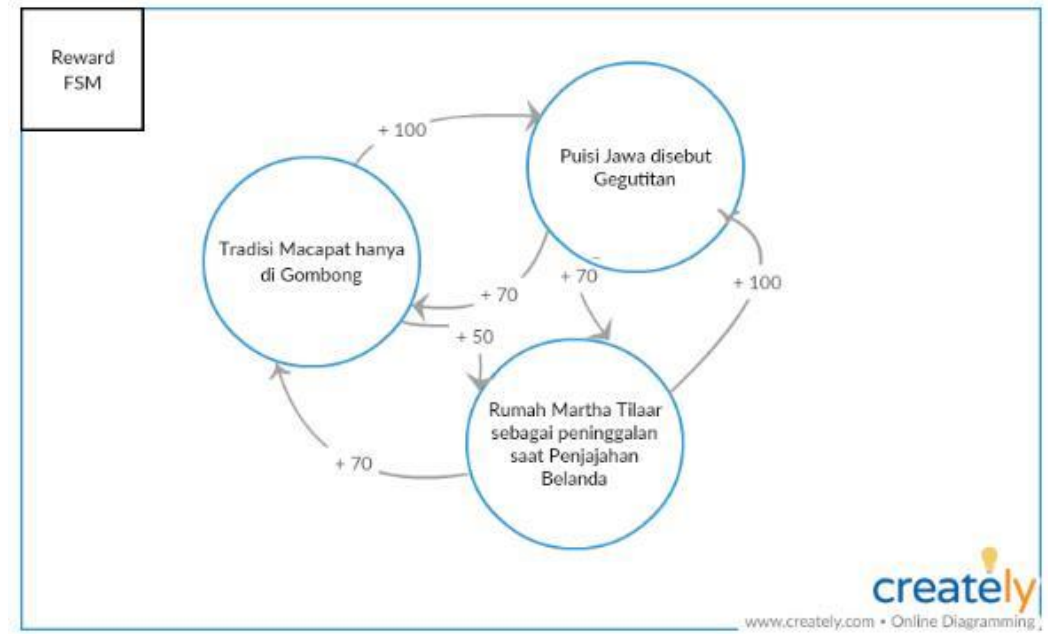

Gambar 7. Contoh reward dinamis pada game. 
Pada gambar 7 di atas merupakan salah satu contoh diagram reward yang ada pada game jika pemain menjawab pertanyaan dengan memilih salah satu jawaban yang ada maka akan ditampilkan poin jawaban pemain pada state_reward, state ini tidak mengubah atau tidak bertransisi ke state lain

\subsection{Pengujian Hasil Perilaku Dinamis yang Dihasilkan Finite State Machine}

Berdasarkan Gambar 6 diperoleh pengujian perilaku dinamis scenario yang dihasilkan oleh Finite State Machine sebagai berikut:

1. Pada initial state 1 kondisi memilih menu skenario_sisipan 1 initial_state akan bertransisi ke skenario_sisipan1 hasilnya memainkan skenario_sisipan1.

2. Pada initial_state 1 jika tidak memilih dari state_prologue maka state tidak bertransisi.

3. Pada initial_state1 memilih skenario_sisipan2 initial_state1 bertransisi ke skenario_sisipan2 hasilnya akan memainkan skenario_sisipan2 .

4. Pada semua state_skenario memilih menu state_save akan bertransisi menyimpan ke state_save hasilnya akan menyimpan ke state_save yang di inginkan

5. Pada semua state_skenario memilih state_load akan bertransisi ke state_load hasilnya memuat game di state_load yang dipilih

6. Pada semua state_skenario memilih state_skip tekan ctrl hasilnya game di skip. Tidak bertransisi game di skip pada current_state

7. Semua state_skenario memilih state_auto tidak bertransisi dan hasilnya game dijalankan otomatis di state_current

8. Semua state_skenario memilih state Q save dan state Qload tidak bertransisi dan hasilnya game akan menyimpan dan meload pada state_current

9. Semua state_skenario memilih menu back tidak bertransisi dan hasilnya kembali ke current_state sebelumnya

10. Semua state_skenario memilih state_history bertransisi ke state history hasilnya akan menampilkan state history ke current_state

11. Initial_state1 memilih pilihan state_reward tidak bertransisi hasilnya menampilkan reward_state

12. Initial_state1 memilih state skenario_sisipan2 bertransisi ke scenario_sisipan2 hasilnya memainkan skenario sisipan2

13. Initial_state1 memilih state scenario_sisipan1 bertransisi ke scenario_sisipan1. Hasilnya memainkan scenario sisipan1

14. Scenario_sisipan1 memilih state_reward tidak bertransisi hasilnya menampilkan state reward

15. Scenario_sisipan1 tidak memilih, langsung bertransisi ke state scenario_utamal hasilnya memainkan scenario utamal

16. Initial_state 2 memilih state_reward tidak bertransisi hasilnya menampilkan state_reward poin

17. Initial_state 2 dipilih dari state_prologue bertransisi ke initial_state 2 hasilnya akan menampilkan skenario awal 2

18. Initial_state2 tidak memilih bertransisi ke skenario_sisipan2 hasilnya memainkan skenario sisipan2

19. Skenario_sisipan2 memilih state reward tidak bertransisi hasilnya menampilkan state_reward

20. Skenario_sisipan2 memilih skenario_sisipan3 bertransisi hasilnya memainkan skenario_sisipan3

21. Skenario_sisipan2 memilih skenario_utama 2 bertransisi ke state skenario_utama2 hasilnya memainkan skenario_utama2

22. Skenario_utama 2 memilih state reward tidak bertransisi hasilnya menampilkan state reward poin

23. Skenario_utama 2 tidak memilih bertransisi ke state_credit hasilnya memainkan state_credit

24. Initial_state3 dipilih dari state_prologue bertransisi ke skenario awal 3 memainkan initial_state3

25. Initial_state3 tidak dipilih bertransisi ke skenario_sisipan3 hasilnya memainkan skenario sisipan3

26. Initial_state3 memilih initial_state4 bertransisi hasilnya memainkan initial state 4

27. Skenario_sisipan3 memilih initial_state4 bertransisi ke initial_state4 hasil nya memainkan skenario awal 4

28. Skenario_sisipan3 memilih reward_state tidak bertransisi hasilnya menampilkan state reward poin 
29. Skenario_sisipan3 memilih skenario_utama3 bertransisi hasilnya memainkan skenario_utama3

30. State_skenario utama3 bertransisi dari state_sisipan3 ke state_utama3 hasilnya memainkan state skenario utama3

31. Initial_state4 memilih state_reward tidak bertransisi hasilnya menampilkan state_reward poin

32. Initial_state4 memilih state_skenariosisipan4 bertransisi ke skenario sisipan 4 dan hasilnya skenario sisipan 4 dimainkan

33. Skenario_sisipan4 tidak dipilih bertransisi hasilnya memainkan skenario_utama4

34. Skenario_utama5 memilih state_skenario goal bertransisi hasilnya memainkan skenario_goal

\subsection{Hasil Implementasi FSM pada Game}

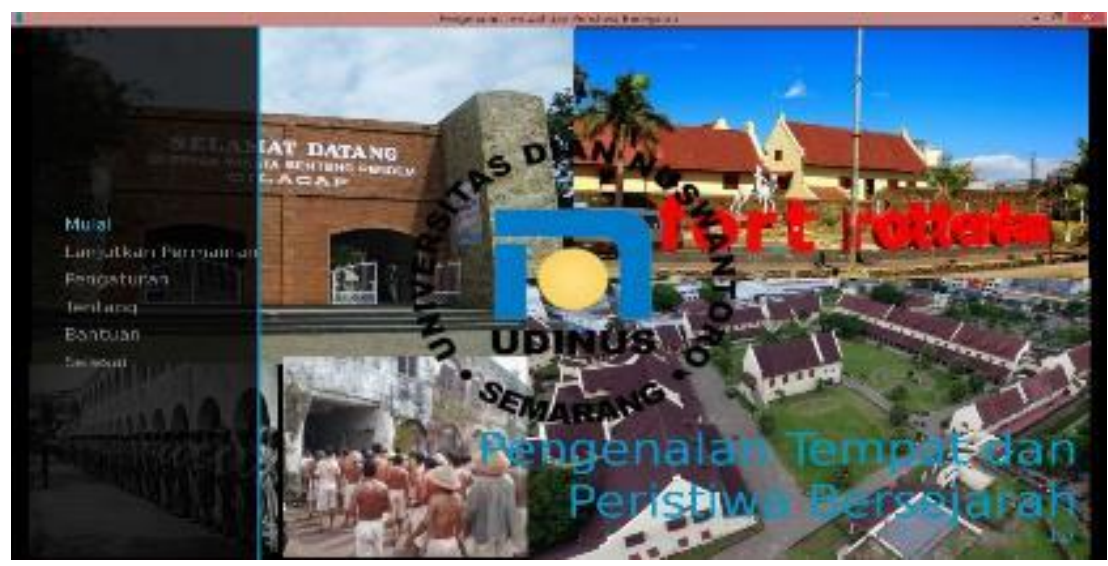

Gambar 8. Interface awal game.

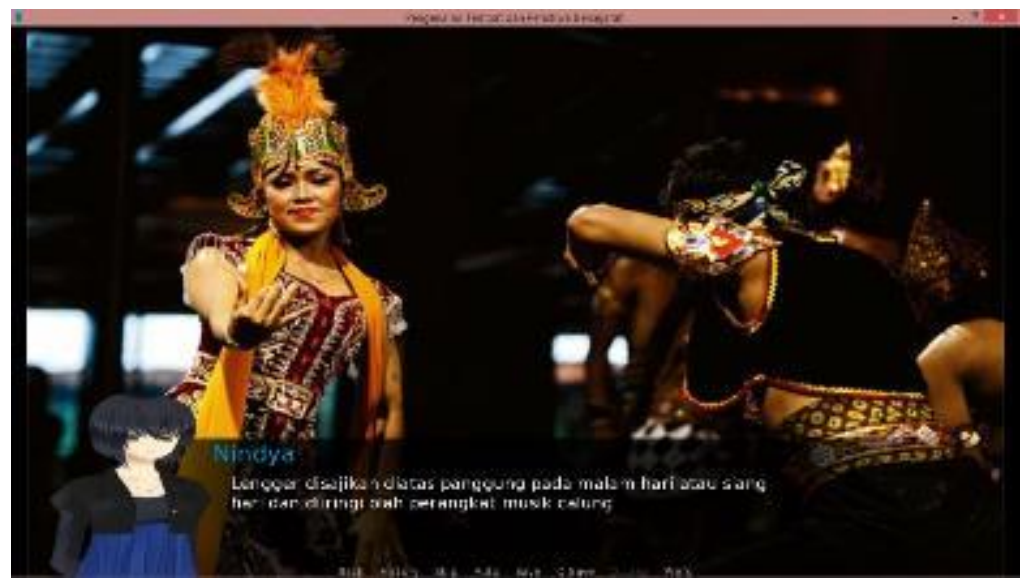

Gambar 9. Skenario yang dipilih pemain. 


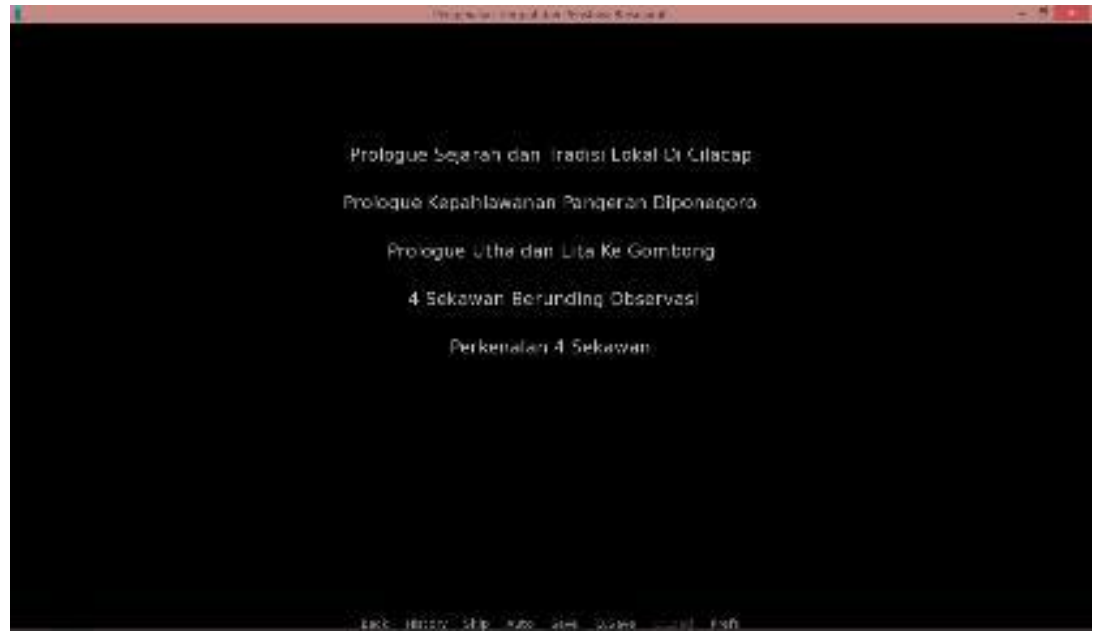

Gambar 10. Pilih skenario awal.

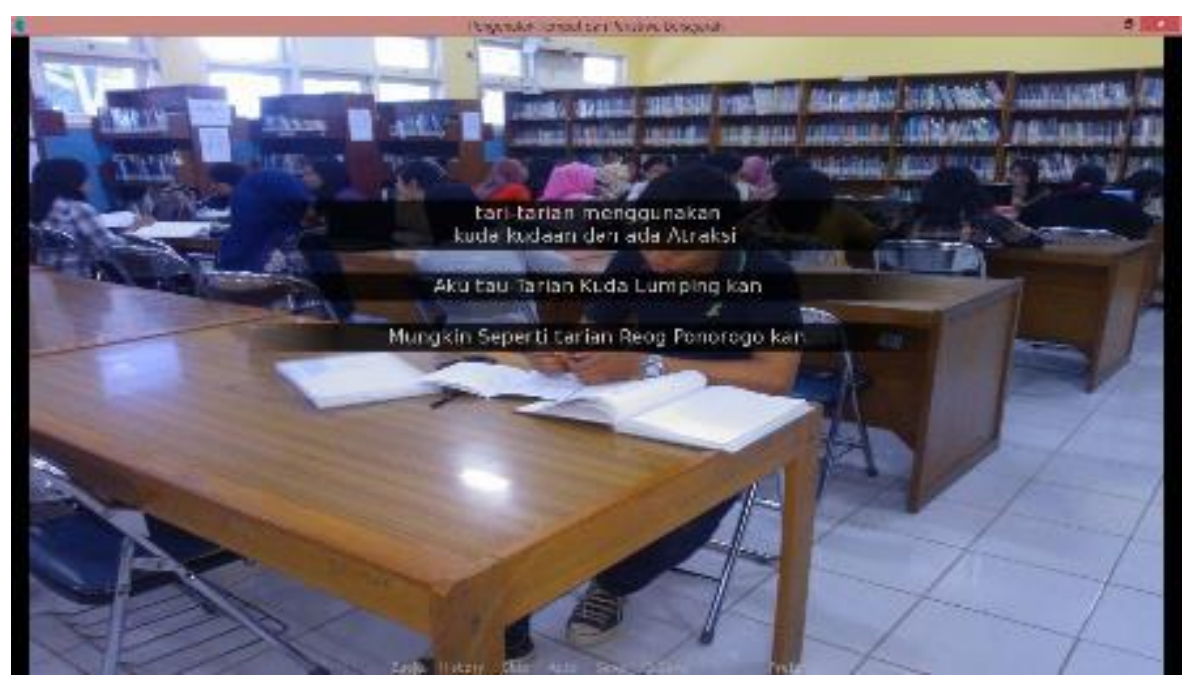

Gambar 11. Pilihan reward game.

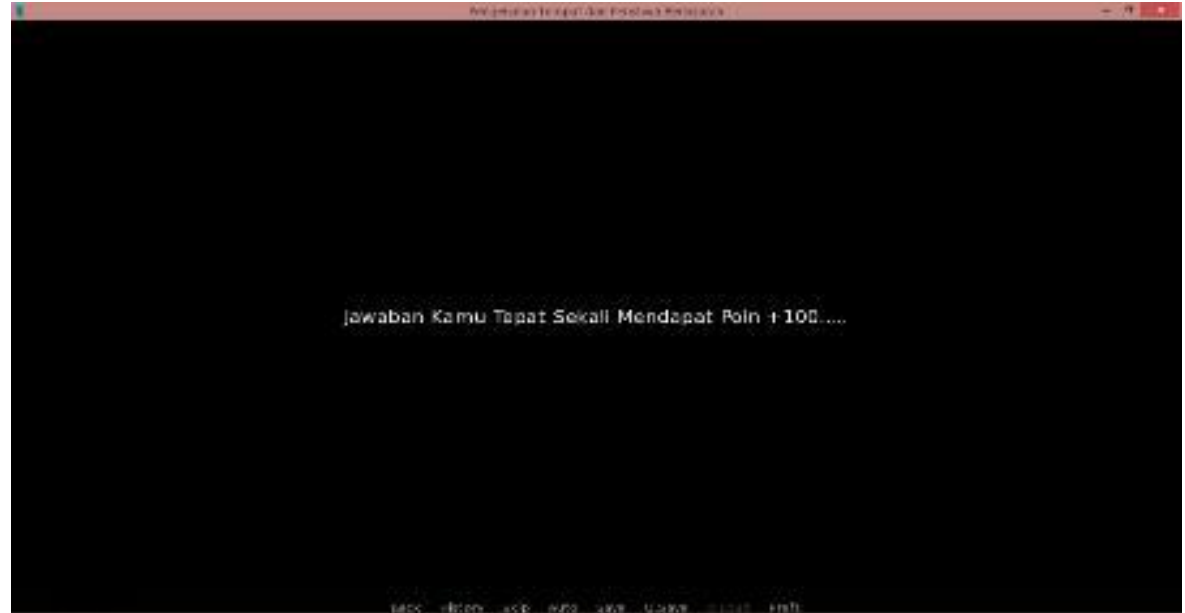

Gambar 12. Reward yang didapatkan oleh pemain. 


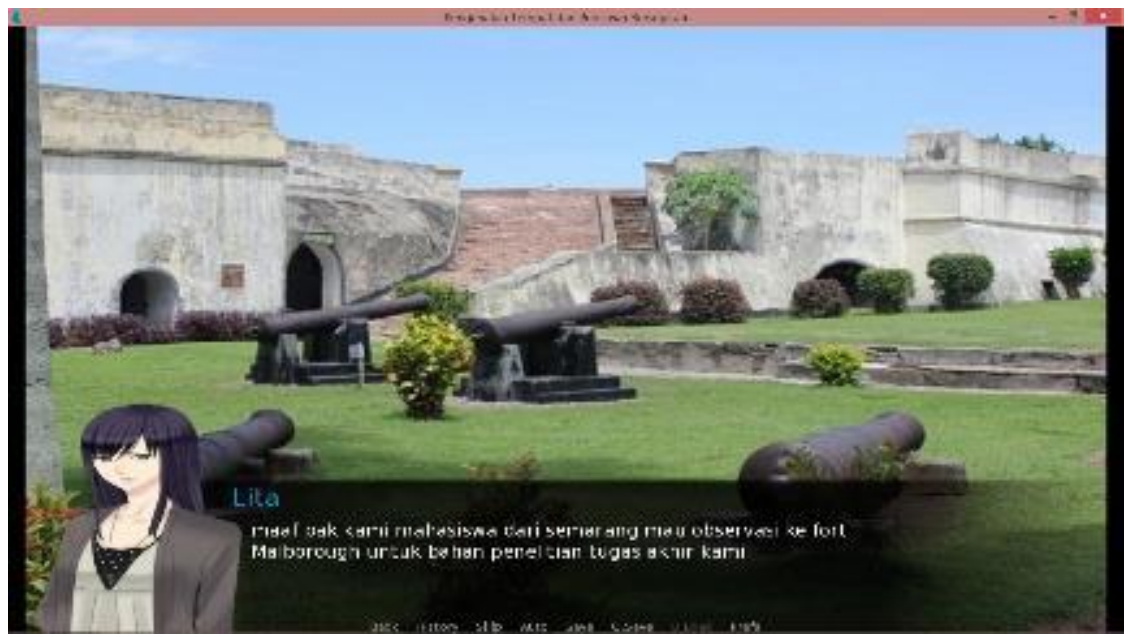

Gambar 13. Skenario utama cerita.

\section{Kesimpulan}

Dari penelitian yang telah dilakukan maka dapat diambil kesimpulan bahwa metode Finite State Machine yang pada penelitian sebelumnya hanya diaplikasikan pada genre game action juga dapat membuat skenario dinamis pada game bergenre visual novel. Dalam penelitian ini, Finite State Machine diimplementasikan pada game bertema sejarah untuk mengatur skenario agar berubah sesuai dengan pilihan atau langkah yang diambil oleh pemain sehingga jika dimainkan kembali dapat menghasilkan perilaku skenario yang berbeda. Hal ini menambah konten dinamis pada game sehingga materi yang disampaikan menjadi tidak membosankan.

\section{Daftar Pustaka}

[1] K. B. B. I. (KBBI), "sejarah.” [Online]. Available: https://kbbi.kemdikbud.go.id/entri/sejarah, diakses 30 Juli 2018.

[2] B. Novandri, "Pengaruh Pemanfaatan Sumber Sejarah Lokal Daerah Sekitar Kota Tegal Terhadap Kesadaran Sejarah Siswa SMA Negeri Se-Kota Tegal,” Universitas Negeri Semarang, 2013.

[3] Putudananjaya, "Benteng Pendem Cilacap," March 10, 2014, 2014. [Online]. Available: https://kebudayaan.kemdikbud.go.id/bpcbjateng/2014/03/10/benteng-pendem-cilacap/, diakses 12 Februari 2018

[4] G. N. Y. and J. Togelius, Artificial Intelligence and Games, 1st ed. Springer, Cham, 2018.

[5] C. T. Agos Jr et al., "Game Development Of Ibong Adarna Visual Novel," Int. J. Sci. Technol. Res., 2013.

[6] E. C. K, "Introduction To Digital Logic Missouri S\&T University CPE 2210 Finite State Machine," 2016. [Online]. Available: http://web.mst.edu/ cetinkayae/teaching/CPE2210Fall2016, diakses 15 November 2018.

[7] H. Tito, Bimantoro1, Hanny, "Pemodelan Perilaku Musuh Menggunakan Finite State Machine (FSM) Pada Game Pengenalan Unsur Kimia," Appl. Intell. Syst., vol. Vol.1, No., pp. 210-219, 2016.

[8] H. Haryanto, "Reward Dinamis Dalam Skenario Adaptif Menggunakan Metode Finite State Machine Pada Game Edukasi," Appl. Intell. Syst., vol. Vol.1, No., pp. 144-153, 2016.

[9] S. M. Miftah Fauzan Rahadian1), Addy Suyatno2), "Penerapan Metode Finite State Machine pada Game 'The Relationship,"” informatika, vol. Vol. 11, 2016.

[10] T. A. Fransnesa1, Wibisono Sukmo Wardhono2, "Pengembangan Permainan Berbasis Augmented Reality pada Perangkat Bergerak sebagai Media untuk Meningkatkan Kepedulian pada Hewan Langka," Pengemb. Teknol. Inf. dan Ilmu Komput., vol. vol 1 no 1, pp. 1089-1099, 2017. 